Kuchuk-Yatsenko, S.I., Havrysh, V.S., Rudenko, P.M., Nakonechny, A.A., Shevchuk, S.A., and Zavertannyi, M.S.

Paton Electric Welding Institute, the NAS of Ukraine,

11, Kazymyr Malevych St., Kyiv, 03150, Ukraine,

+380 44205 2370; +380 44568 0486, office@paton.kiev.ua

\title{
DEVELOPMENT OF RESISTANCE BUTT WELDING TECHNOLOGY AND PROTOTYPE EQUIPMENT FOR JOINING CARBIDE BAR CHAIN RIPPER TEETH OF VK-8 MATERIAL
}

Introduction. The need for welding hard alloys with steel occurs in the tool industry and in other engineering industries while manufacturing carbide blanks that cannot be produced by conventional methods of powder metallurgy because of their size or configuration.

Problem Statement. The ripper teeth manufacturing from the hard alloys of the tungsten-cobalt group VK8 and steel $40 X$ is an important and urgent task for improving of the bar chain operational reliability. In world practice, the soldering technology is used in an inductor or a gas flame with silver-based solders for manufacturing the teeth. However, this process is characterized by a low productivity and a high cost.

Purpose. Development of highly effective and relatively cheap technology to produce the bar chain ripper teeth and equipment for its implementation.

Materials and Methods. The research has been carried out on industrial samples of VK-8 hard alloy and $40 X$ steel. The welded joint microstructure has been studied by optical and electron microscopy.

Results. The resistance welding technology of carbide bar chain ripper teeth from material VK-8 and steel $40 \mathrm{X}$ with the use of an intermediate composite layer has been developed. Experimental equipment based on resistant welding machine and computer control system has been created. Metallographic studies of weld joints have shown that the joints have no defects. The tests of the welded bar chain ripper teeth have proved that they provide the required service life.

Conclusions. The developed technology and equipment enable to reduce the cost and to increase the productivity of the welding process in comparison with the existing technologies. It has enabled to replace the imported bar chain ripper teeth with domestic products.

Keywords: resistance welding, intermediate composite layer, carbide materials, and computer control system.

In its activities, Ukrzaliznytsia's Center for Repair and Operation of Road Vehicles uses machines for deep reclaiming of ballast. Recently, major railway repairs and reclaiming of the ballast prism have been made using bar-type ballast

(C) KUCHUK-YATSENKO, S.I., HAVRYSH, V.S., RUDENKO, P.M., NAKONECHNY, A.A., SHEVCHUK, S.A., and ZAVERTANNYI, M.S., 2019 cleaning machines such as RM-80, SCh-1000, SchOM-6. When planning railway repair works for the coming years, main attention is paid to the clearing machines. The main working unit of these machines, which cuts out and removes ballast from the track panel (assembled rails and sleepers), is the rake equipped with a bar chain. This chain operates in high load conditions and 
has teeth with hard band of foreign or domestic production. The performance and efficiency of the operation of the whole machine depends on the state and reliability of the bar chain operation [1].

The bar chain is a heavy-duty device. Intensive abrasive wear is combined with high static and dynamic loads that arise when working with over-compacted ballast. Therefore, the design and quality of bar chain manufacture subject to strict requirements, and the chain condition is constantly controlled by the service team. The service life of the chain essentially depends on the material of its components, technology and quality of their manufacture; its design enables to extend the service life by changing the worn parts [1].

Ripper shaped as conical tooth plays an important role in the bar chain operation. New rippers significantly cut energy costs for the excavation of ballast, increase machine performance, and reduce the load on the chain and the drive mechanisms. During the operation, it is necessary to control the ripper condition, to replace in due time the worn out ones and to restore the lost elements that are better to be made of alloyed steels or with brazing hard-alloy materials. The rippers, as a rule, are repaired as the chain has worked out 7-10 km [1].

Replacing the bar chain is a labor-intensive and expensive process, so it is important to find ways to extend the chain service life and to raise its efficiency. One of the options is a selective replacement of individual parts of the chain, in particular, the ripper teeth [1]. The tooth consists of a steel holder and a ceramic-metal hard-alloy tip welded onto the holder.

The existing technologies for coupling hardalloy tips made of VK8 type material with a tooth holder do not always meet modern quality and performance requirements. In particular, the induction soldering technology does not provide stable quality of joints and requires soldering with the use of precious silver. The technology for diffusion welding in vacuum, which is used in the manufacture of punches, cutting dies, etc., has a low productivity, therefore, it is ineffective for industrial manufacture of ripper teeth [5-9].

The replacement of existing technologies for welding metal-ceramic hard alloys with steel by a new one that has been developed as a result of the implementation of an innovative project will enable to significantly save the material and technical resources of enterprises, to raise the performance of equipment and to improve working conditions, as well as to reduce energy consumption.

\section{RESISTANCE WELDING AND PROTOTYPE EQUIPMENT}

In order to eliminate the disadvantages of existing technologies (low productivity, high cost, instability of the weld quality) and to ensure a proper strength of the welded joint, a new technology for resistance welding based on the use of intermediate composite layers according to the Ukrainian patent UA 78378 C2 and Patent USA No. 8,426,762 B2 has been offered. The layers are thin profiled metal films filled with a layer of flux. The fuse insert is placed between the welded parts, increases the resistance in contact between them and provides localization of heating in the weld zone. At the same time, in the contact zone, a weld with given thickness and mechanical properties is formed. Also, the influence of the element composition of the composite layer on the magnitude of its resistance and the heat concentration during resistance welding, because it determines the mechanical properties of the weld joint [2-4], has been studied.

The work has been carried out in the following directions:

+ analyzing the available methods for contact welding with layers;

+ developing the heating/cooling technological cycle;

+ choosing the material and the form of intermediate layer;

+ selecting and testing the basic parameters of the welding conditions; 


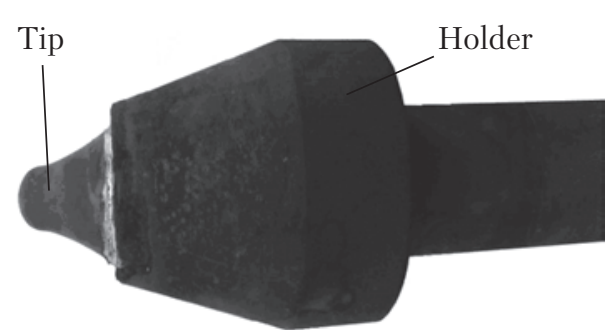

Fig. 1. Bar chain ripper tooth

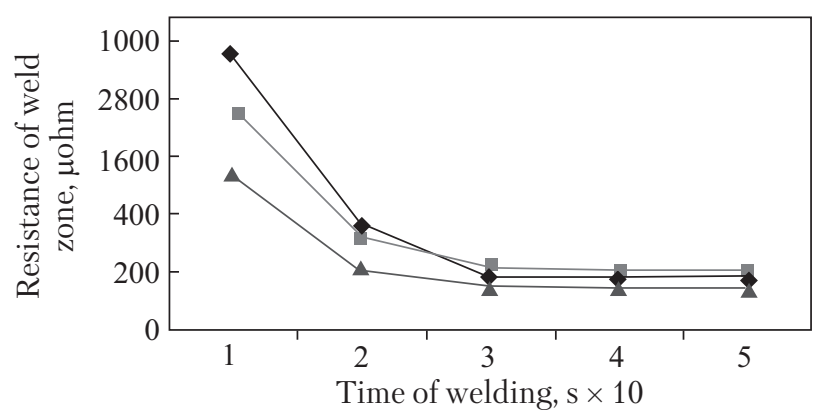

Fig. 2. Electric resistance of welding zone of three specimens

+ developing and producing prototype equipment and additional process plants;

+ conducting experiments on welding ripper teeth;

+ conducting mechanical tests;
+ selecting sensors for control of the main parameters of welding conditions;

+ developing and manufacturing the computer system for control of welding process.

The object of this research is a bar chain ripper tooth that consists of a tip made of VK8 hardalloy material and a holder made of $40 \mathrm{X}$ steel (Fig. 1).

The equipment for resistance welding of ripper tooth can be divided into the following components: a welding machine, a control system, and a process plant.

The choice of welding machine depends on the size of parts to be welded, as well as on the thermal deformation cycle that provides the necessary heating and deformation of these parts. Previous experiments have shown that this requires using a contact point machine with an additional intermediate electrode and a specialized control system.

The thermal deformation welding cycle should ensure melting the layer in the flux medium while the materials of the holder and the tip remain unmelted.

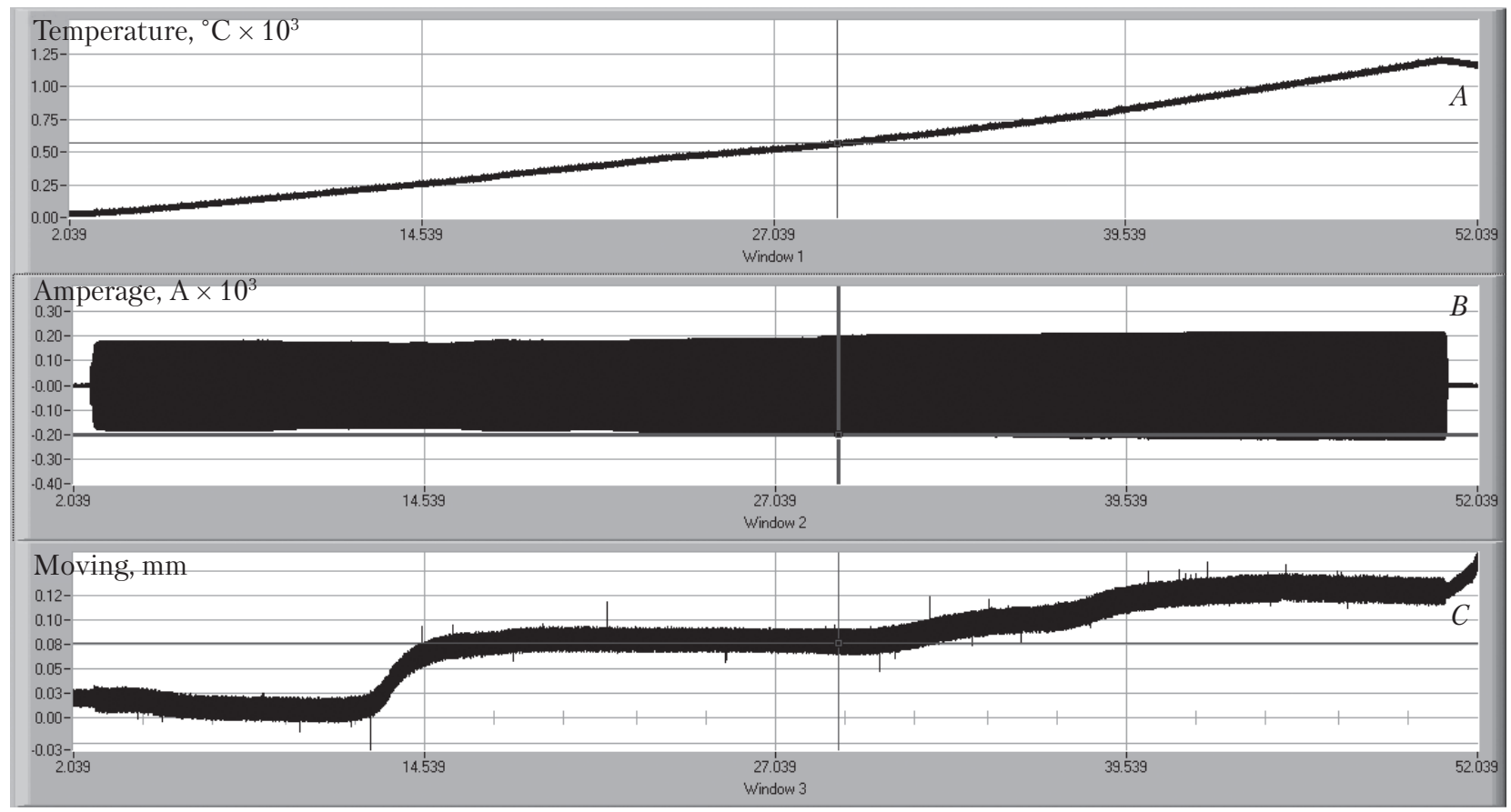

Fig. 3. Oscillogram of the process parameters in the case of tooth welding: $A$ - layer zone temperature; $B$ - current in the primary winding of welding transformer, $C$ - upper electrode displacement 
Preliminary estimates and experimental studies have shown that the welding cycle for the holder of 40X steel and the tip of VK8 hard alloy should start with the current modulation and its increase in the second part of the cycle. The welding process is completed when the layer temperature reaches the melt point and followed by keeping the welded layer under current. The electric resistance of the weld zone at the beginning of the process has been estimated to vary within $500-900 \mu \Omega$, while in the second half of the process the range is narrowed to $180-210 \mu \Omega$, which gives reason to consider the process to be stable (Fig. 2).

To control the welding process and to assure the required quality of joints, sensors of current, voltage between the electrodes, the upper electrode displacement, and the layer melting zone temperature are installed on the contact machine. The electrical signals from these sensors are registered by 8-channel computer system. The oscillogram of the welding process parameters is shown in Fig. 3.

The analysis of oscillograms of upper electrode displacement has shown that the initial voltage from the sensor varies significantly depending on the variation of the linear dimensions of the welded parts - the holder and the tip. The tip height has been selectively measured to range within $2.1-2.3 \mathrm{~mm}$, whereas the upper electrode displacement in the course of welding does not exceed $0.5 \mathrm{~mm}$. In addition, the electrode displacement increases unevenly, which can be explained by local splashes of the molten metal of the interlayer.

Having measured the upper electrode displacement before and after the welding of the tooth parts it is found that the electrode displacement varies in a wide range. Thus, for sample 1 , the index $\delta$ is $0.22 \mathrm{~mm}$, whereas for the sample 3 , $\delta=0.02 \mathrm{~mm}$. At the same time, the weld quality evaluated for macro-sections and by the molten layer between the holder and the tip remains the same, at a proper level, and sufficient for both samples.

ISSN 2409-9066. Sci. innov. 2019, 15(1)
$+24 \mathrm{~V}$

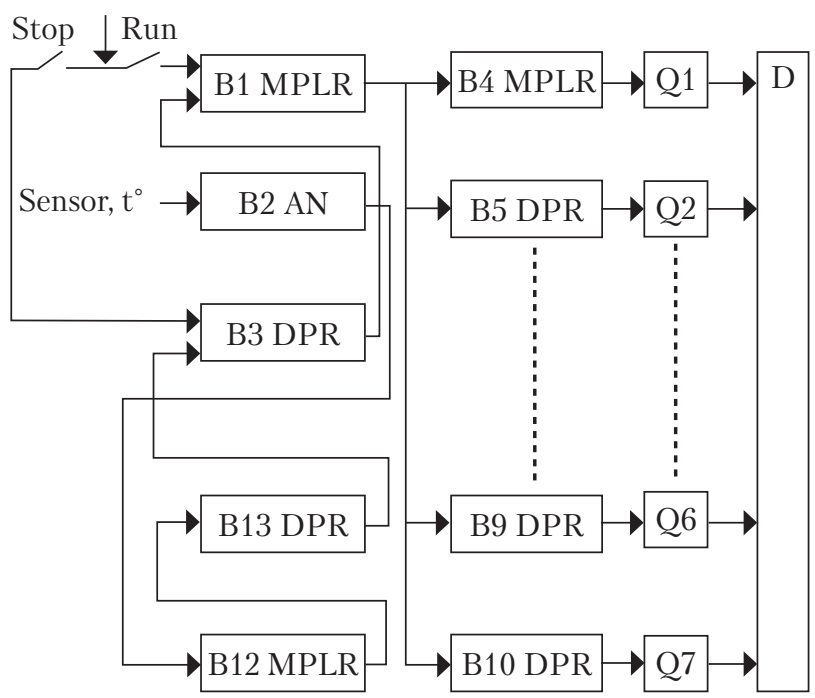

Fig. 4. Schematic diagram of the controller functional blocks: B1 - block for setting of welding time and welding process control; B2 - block for comparing the actual temperature in the welding zone with the preset temperature, B3 - block for stopping the welding process by operator, B4-B10 - welding current control blocks; B12, B13 blocks for automatic stopping of welding process

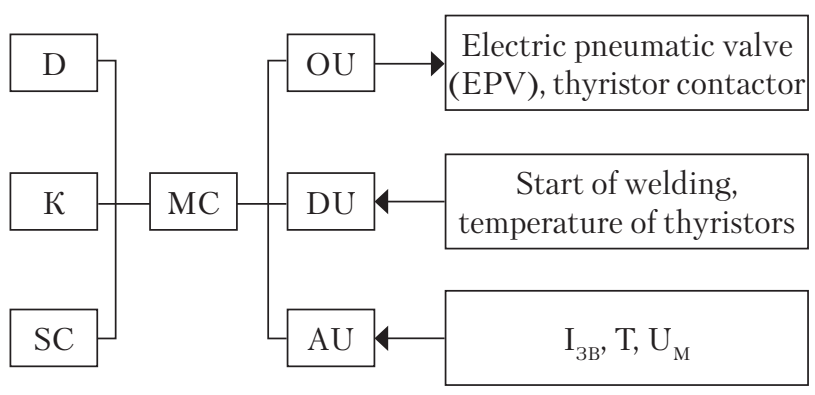

Fig. 5. Structural diagram of CCS CS 02B: MC - microcontroller, DU - discrete signal input unit, AU - analog signal input unit, OU - control signal output unit, SC serial communication channel, D - display, $\mathrm{K}$ - keyboard

The displacement fluctuations also depend on the height of the tooth tip, which makes up near $25 \%$ of the total height of the part. The oscillogram of welding process parameters, including the layer zone temperature, is shown in Fig. 3. Unlike the displacement, the layer zone temperature varies linearly and reaches its maximum at the end of the process. 


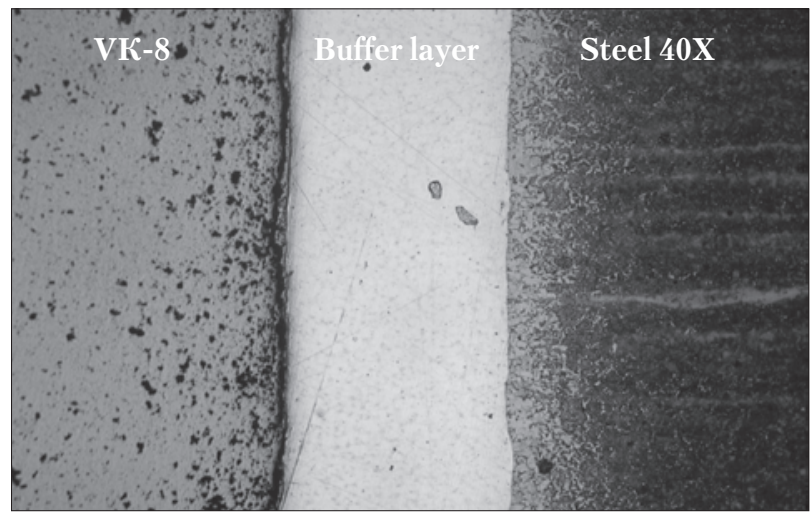

Fig. 6. Macro-section of VK8+ 40X steel joint $(\times 100)$

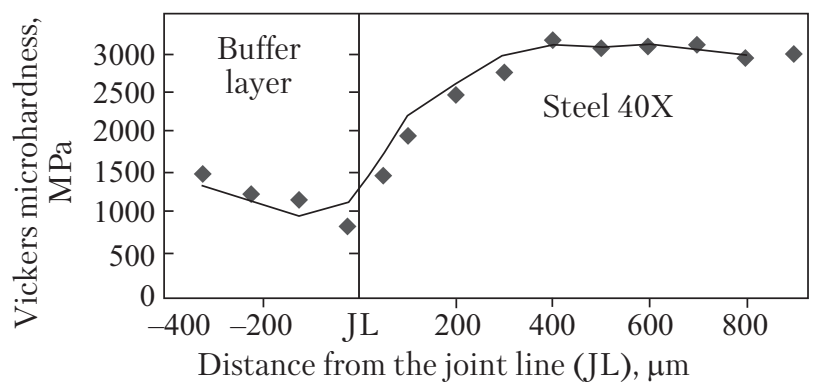

Fig. 7. Measurement of micro-hardness of the joint's HAZ

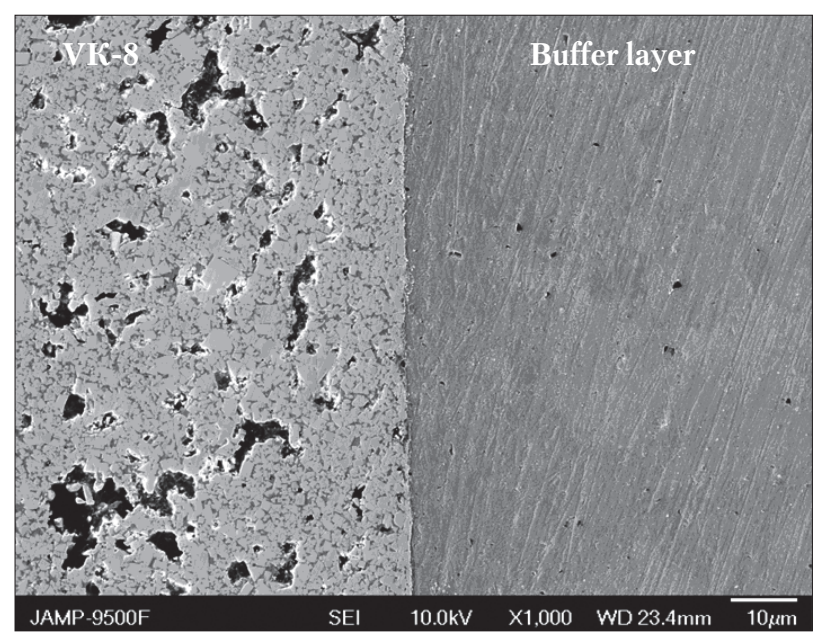

Puc. 8. Micrograph of VK8-intermediate layer joint line $(\times 1000)$

The analysis of oscillograms of the welding process parameters has shown that the layer zone temperature unconditionally correlates with the weld joint quality, therefore, this parameter is used for control purposes.

\section{WELDING PROCESS CONTROL SYSTEM ON PROGRAMMABLE CONTROLLER}

The control system is based on programmable controller of $F A B A F-20 M R-D$ type manufactured by Array Electronic Co., Ltd.

The FAB controller belongs to a new generation of programmable controllers that are programmed by building functional block sequences, which is much simpler than the programming of the controllers of previous series.

There are 20 general types of functional blocks, each of them can have a special configuration, such as time delay of "switch-on", "switch-off", "duration of switch-on", "counter", etc. Inasmuch as the functional blocks can be connected both in series and in parallel, it is possible to implement rather complicated control tasks.

The welding machine control is exercised by the FAB controller that is programmed for processing the cyclogram consisting of the initial modulation of the welding current, the duration of welding, the control of current and voltage disconnection as given temperature of the welding zone is reached. Schematic diagram of functional blocks is shown in Fig. 4.

The duration of the welding operation is set and maintained by the block B1, and the current is regulated by the blocks $\mathrm{B} 4-\mathrm{B} 10$. The voltage of the welding zone temperature sensor is compared with the required one using the block B2. When the temperature reaches a desired value, the welding process is stopped by the control signal from the comparator B2 (blocks B12, B13, B3). The operator can stop the welding process manually, using the "stop" button through the block B3.

\section{COMPUTER CONTROL SYSTEM CCS CS 02B}

Computer control system CCS CS 02B is designed for controlling the welding of bar chain elements using an $\mathrm{AC}$ contact point machines [10].

The control system functions are as follows:

+ to set up and to maintain the welding cyclograms: preliminary compression, compression, welding 1 with current modulation 1, pause 


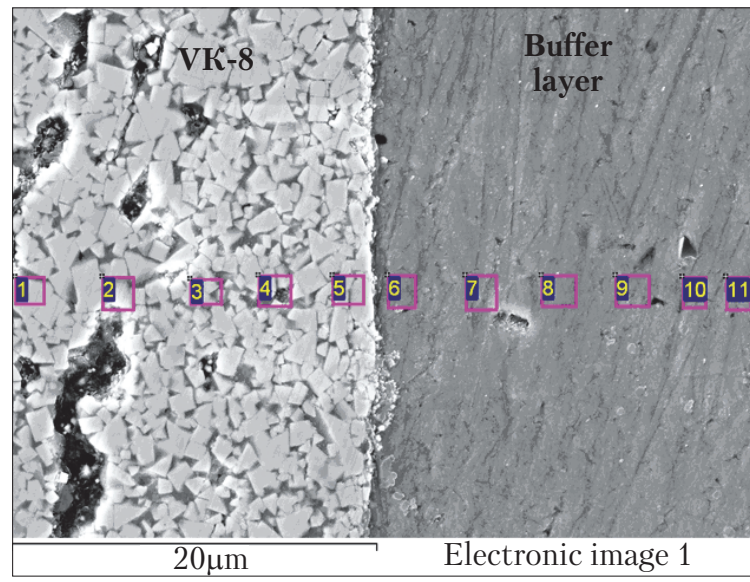

$a$

\begin{tabular}{|c|c|c|c|c|c|c|c|}
\hline Spectrum & $\mathrm{C}$ & $\mathrm{Fe}$ & $\mathrm{Co}$ & $\mathrm{Cu}$ & $\mathrm{Zn}$ & $\mathrm{W}$ & Итог \\
\hline 1 & 5.24 & 0.14 & 9.17 & 0.37 & 0.00 & 85.08 & 100.00 \\
2 & 5.80 & 0.37 & 15.66 & 1.17 & 1.04 & 75.96 & 100.00 \\
3 & 5.13 & 3.50 & 15.22 & 5.76 & 3.96 & 66.44 & 100.00 \\
4 & 6.71 & 5.04 & 13.14 & 6.41 & 4.01 & 64.67 & 100.00 \\
5 & 5.87 & 3.64 & 2.62 & 6.91 & 3.89 & 77.07 & 100.00 \\
6 & 2.15 & 0.90 & 0.87 & 60.29 & 33.43 & 2.36 & 100.00 \\
7 & 1.93 & 0.84 & 0.88 & 60.90 & 33.67 & 1.78 & 100.00 \\
8 & 2.47 & 0.69 & 0.46 & 60.29 & 34.42 & 1.67 & 100.00 \\
9 & 2.77 & 0.61 & 0.45 & 58.50 & 36.40 & 1.26 & 100.00 \\
10 & 2.95 & 0.96 & 0.46 & 59.11 & 34.90 & 1.63 & 100.00 \\
11 & 2.30 & 0.93 & 0.64 & 61.24 & 33.32 & 1.58 & 100.00 \\
\hline
\end{tabular}

Fig. 9. Micrograph of VK8-intermediate layer joint line $(a, \times 4000)$ with X-ray analysis sites $(1-11)$ and its results $(b)$

Fig. 10. Alloy element distribution in the VK8-intermediate layer weld joint

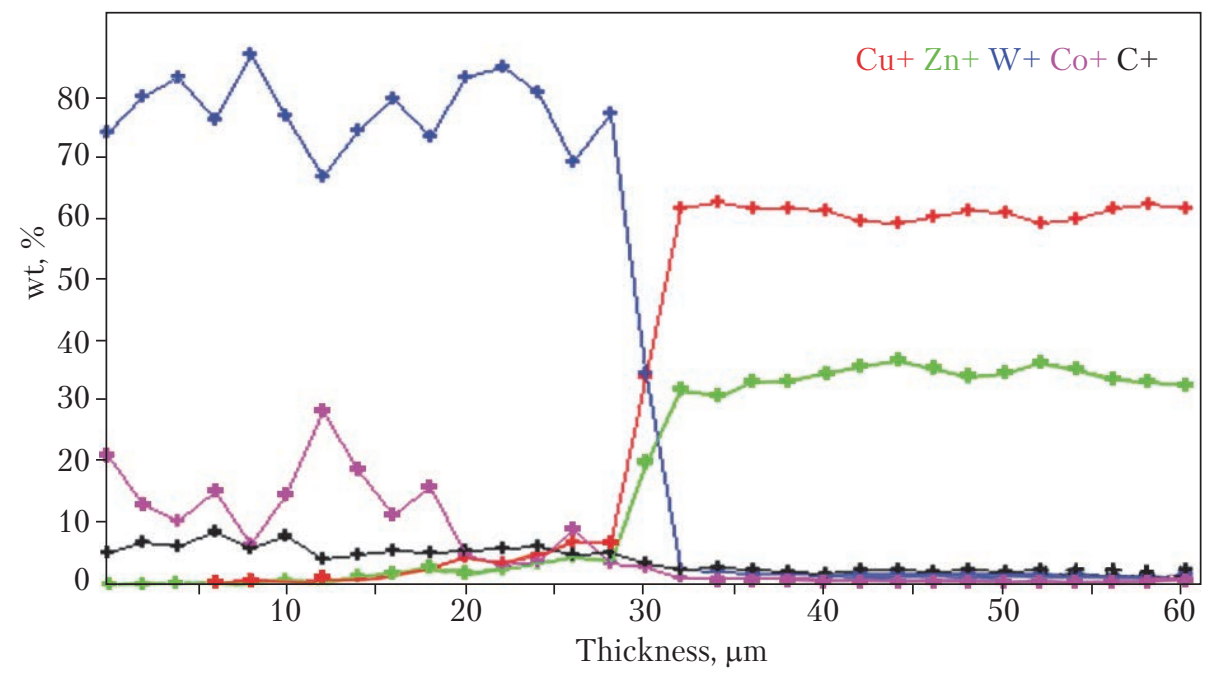

Thickness, $\mu \mathrm{m}$ with the possibility of frequent repetition, cooling, welding 2 with current modulation 2 , forging with the inclusion of hammering while the current is flowing, pause;

+ to control of thyristor contactor and four electro-pneumatic valves;

+ to compensate fluctuations of voltage in the power supply grid;

+ to stabilize the effective value of welding current;

+ to automatically adapt to $\cos (\varphi)$ of the welding machine;

+ to measure welding current, temperature of the welding components at the place of welding, and voltage of the power supply grid;
+ to control the welding quality with allowable variation of welding current and/or temperature at the welding area and/or to predict the quality of weld joints by mathematical model or neural network;

+ to save in the system memory eight specified welding conditions when voltage is disconnected;

+ to select automatically any of the eight preset modes by external control signal;

+ to provide self-diagnostics of the system;

+ to communicate with a personal computer via serial communication channel RS 232 or RS 485; and 

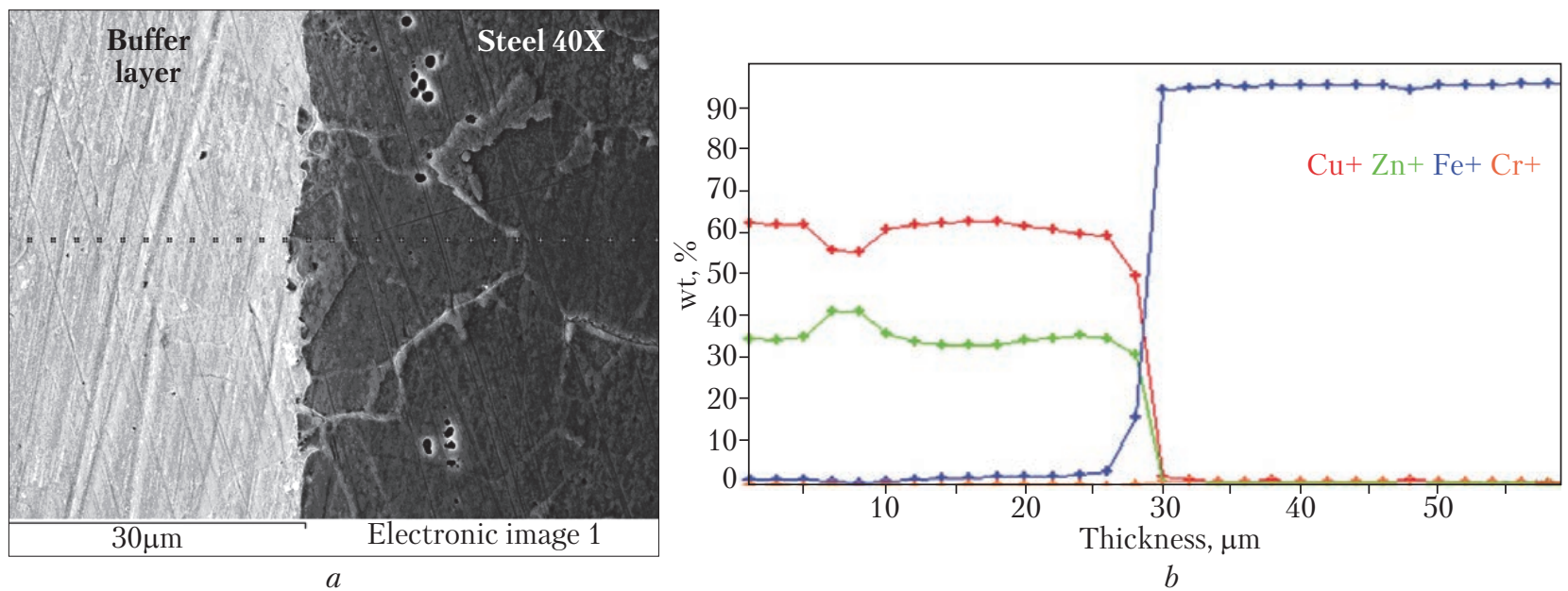

Fig. 11. Intermediate layer-40X steel joint line $(a, \times 4000)$ and results of X-ray analysis of element distribution analysis in the weld area $(b)$

+ to provide a software protection against unauthorized access to setting the welding parameters.

The system configuration is shown in Fig. 5.

Through the DU node the microcontroller reads the signals of discrete sensors (start of welding, thyristor overheating sensor, thyristor conductivity control, etc.); through the AU node, it processes the readings of welding current sensors, sensors of temperature at the welding area and voltage of the power supply grid. The welding parameters are input and controlled with the help of a keyboard. The specified and measured parameters are shown on the display. The control signals are output to the electro-pneumatic valves and thyristors via the OU node. At the end of the welding process, the data on the process parameters can be transmitted to the personal computer or the contact welding control system through the serial communication channel of the personal computer.

The process is controlled based on welding current and welding area temperature tolerances at the end of the first current pulse. The current tolerance is $6 \%$ of the preset current value, the temperature tolerance is $12 \%$ of the preset temperature value. If the parameters exceed the permissible values, an appropriate diagnostic mes- sage appears on the display, with an external signal (sound or light) is triggered.

\section{METALLOGRAPHIC STUDIES}

The joint is formed uniformly throughout the thickness, with no residual slag inclusions observed. The study of macro-sections (Fig. 6) has showed that the interlayer thickness under optimal welding conditions is $0.28-0.34 \mathrm{~mm}$, with the mechanical properties of displacement being $\tau=240-260 \mathrm{MPa}$. Reducing the layer thickness increases residual internal stresses, which leads to a decrease in shear strength. Increasing the layer thickness also reduces the mentioned strength, apparently, as a result of reducing the "thin layer" effect between two plates with much higher rigidity.

In the heat-affected zone (HAZ), on 40X steel, at a depth of up to $120 \mu \mathrm{m}$, there is an overheated zone with the formation of finely dispersed bainite-pearlite structure with areas of hypo-eutectoid ferrite, which means a cooling rate after welding is more than $200{ }^{\circ} \mathrm{C} / \mathrm{s}$. Such a narrow HAZ is obtained due to a high specific heat output and a short welding time. The area of complete recrystallization has a granular ferrite-perlite structure. The area of incomplete recrystallization is characterized by heterogeneity and the presence 
of zones with increased micro-hardness of up to $3200 \mathrm{MPa}$. While determining the HAZ microhardness (Fig. 7), measurements are made for the intermediate layer and for $40 \mathrm{X}$ steel. No measurements are done for the hard alloy VK8, because of a high hardness of tungsten carbide grains and the powder structure of this composite.

The HAZ micro-hardness has been established to decrease at a depth of up to $300 \mu \mathrm{m}$. The further study with the use of optical microscopy at magnifications over $\times 400$ has shown neither the formation of new phases on the joint line nor the melt penetration into the VK8 material.

Subsequently, cohesive interaction of the weld materials has been studied by the electron microscopy method using a raster electron microscope JAMP-9500F, JEOL (Japan), with a LINK860/500 energy-dispersion analyzer, LINK (UK) (Figs. 8-11).

Figs. 12-13 show fracture patterns of the surface of weld samples VK8 + 40X after the shear and impact fracture tests. In both cases, the destruction occurs in the hard alloy, because of concentrated internal stresses in the contact area of VK8. The granular structure of the metal-ceramic hard alloy is clearly visible. However, there is no reason to assume a completely brittle fracture in this case, since there are "tongues" and "fissures", which testify to a partial plastic deformation. The brittle fracture on carbide particles may also be delayed due to the formation of small cleavage ridges, indicating a partial plastic deformation. In some areas, there are steps that form star-shaped fractures whose lines are located at different angles. Here, the destruction is more brittle as compared with the formation of steps with smooth outlines having a curved trajectory. Despite an insignificant role of plasticity in the formation of steps, it can significantly change the work spent on the destruction. The direction of local destruction varies considerably while transiting from one grain to another. On the microfracture patterns given below, one can see a quasifracture. This type of destruction, along with the characteristic features of the brittle fracture, has

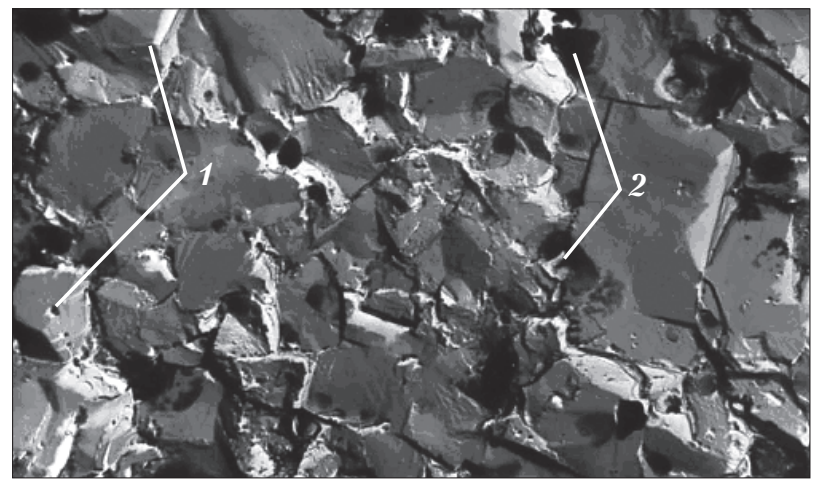

Fig. 12. Fracture pattern of $\mathrm{VK} 8+40 \mathrm{X}$ specimen after the shear test $(\times 10000)$ : 1 - "tongues", 2 - "fissures"

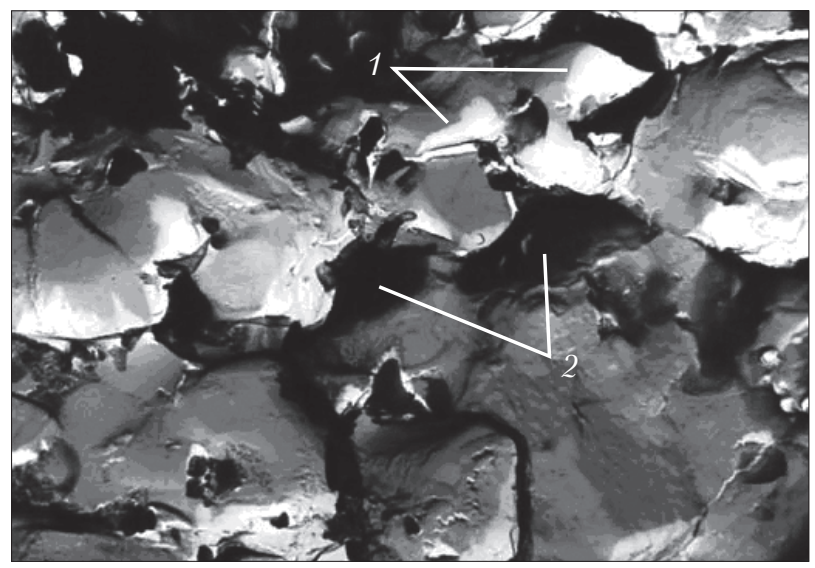

Fig. 13. Fracture pattern of VK $8+40 \mathrm{X}$ specimen after the impact test (×10000): 1 - "tongues", 2 - "fissures"

some residual plastic deformation and is a transition from very brittle to plastic fractures. The quasi-fracture is a brittle fracture in adjacent small areas uniting them into a single fracture surface with some plastic deformation. The features of the brittle fracture structure, such as steps in the form of ridges, chips, and tongues are typical for the quasi-fracture.

Thus, the proposed method for resistance welding with a composite layer enables to obtain a qualitative joint of VK8 hard alloy material with 40X steel for the manufacture of bar chain ripper teeth, which is notable for a high productivity and a low cost.

The metallographic study of weld metallographic specimens by the optical and raster electron microscopy methods has shown a narrow 
HAZ, a permissible reduction in micro-hardness and the absence of macro-defects. The experimental studies and analysis of control parameters and control of resistance welding with a composite layer have shown that the welding zone temperature as measured by an infrared sensor correlates with the weld quality and can be used as a control parameter.

The developed automatic welding control sys- tems based on a programmable controller and a specialized computer system provide a stable cycle of welding and control over the welding zone temperature. The designed research equipment for resistance welding of hard-alloy bar chain ripper teeth of VK8 material provides an appropriate thermal deformation cycle, automatic control of the process and can be used to design a preproduction prototype.

\title{
REFERENCES
}

1. Increase of durability of bar chains. URL: http://scbist.com/xx1/24786-02-1999-povyshenie-dolgovechnosti-barovyh-cepei.html (Last accessed: 29.03.2018) [in Russian].

2. USA Patent № US 8,426,762 B2. Kuchuk-Yatsenko V. S., Nakonechnyi A. A., Sakhatskiy A. G. Metod of resistance butt welding using corrugated flux-filled metal inserts.

3. Patent of Ukraine UA 78378. Kuchuk-Yatsenko V. S., Nakonechnyi A. A., Sakhatskiy A. G. Method of resistance welding.

4. Kuchuk-Yatsenko, S. I., Zyakhor, I. V., Chernobay, S. V., Nakonechny, A. A., Zavtitaniy, M. S. (2015). Structure of titanium aluminum-titanium compounds $\gamma$-TiAl at resistance butt welding using interlayers. Automatic welding, 9, 7-15 [in Russian].

5. Welding of hard alloys with steels. URL: http://mash-xxl.info/info/678604 (Last accessed: 29.03.2018).

6. A. s. USSR No. 1194630 A. The method of diffusion welding of a hard alloy with steel. V. Y. Nechaev, A. V. Sergeev. № 3785935 / 25-27 claimed. 28.06.84; publ. 30 11.85, Bul. F 44.

7. Soldering of metal-ceramic hard alloys. URL: http://www.drevniymir.ru/vostok02.html (Last accessed: 29.03.2018).

8. Soldering technologies. Soldering of metal-ceramic hard alloys. URL: http://www.bsn-media.ru/?cat=48 (Last accessed: 29.03.2018).

9. Recommendations of CPC for soldering hard-alloy plates. URL: http://www.ritscomp.ru/TV_SP/rekomendacii/ rekom_5.htm (Last accessed: 29.03.2018).

10. Krivenko, V. G., Rudenko, P. M., Gavrish, V. S. (2004). Computer control system KSU KS02 for contact point machines. Welder, 3(37), 3 [in Russian].

Received 24.04.18

\author{
С.І. Кучук-Яченко, В.С. Гаврии, П.М. Руденко, \\ А.О. Наконечний, С.А. Шевчук, М.С. Завертанний \\ Інститут електрозварювання ім. Є.О. Патона НАН України, \\ вул. Казимира Малевича, 11, Київ, 03150, Україна, \\ +380 44205 2370; +380 44568 0486, office@paton.kiev.ua

\section{РОЗРОБКА ТЕХНОЛОГІЇ ТА СТВОРЕННЯ ДОСЛІДНОГО УСТАТКУВАННЯ \\ ДЛЯ КОНТАКТНОГО ЗВАРЮВАННЯ ОПОРОМ ТВЕРДОСПЛАВНИХ ЗУБІВ РОЗПУШУВАЧА БАРОВОГО ЛАНЦЮГА З МАТЕРІАЛУ ВК-8}

Вступ. Необхідність зварювання твердих сплавів зі сталлю виникає в інструментальній промисловості і в низці процесів у машинобудівній галузі при виготовленні твердосплавних заготовок, які за своїми габаритами або конфігурацією не можуть бути отримані звичайними методами порошкової металургії

Проблематика. Виготовлення зубів розпушувача з твердих сплавів вольфрам-кобальтової групи ВК8 та сталі $40 \mathrm{X}, €$ важливим та актуальним завданням для підвищення експлуатаційної надійності барового ланцюга. У світовій практиці при виготовленні його зубів використовують технологію пайки в індукторі або газовим полум'ям з припоями на основі срібла. Проте такий процес є низькопродуктивним та високовартісним.

Мета. Розробка високоефективної та відносно дешевої технології виготовлення зубів розпушувача барового ланцюга та експериментального обладнання для iï реалізації. 
Матеріали й методи. Дослідження проводились на промислових зразках із твердого сплаву ВК-8 та сталі 40Х. Мікроструктуру зварних з'єднань досліджували методами оптичної та електронної мікроскопії.

Результати. Розроблено технологію контактного зварювання опором твердосплавних зубів розпушувача барового ланцюга з матеріалу ВК-8 зі сталлю 40Х з використанням проміжного композиційного прошарку. Створено дослідне устаткування на основі машини для контактного зварювання та комп’ютерної системи управління. Металографічні дослідження зварних з'єднань показали відсутність у них дефектів. Проведені випробування зубів розпушувача барового ланцюга довели, що вони забезпечують належний ресурс експлуатації.

Висновки. Розроблена технологія та устаткування дозволяють значно знизити собівартість та підвищити продуктивність процесу зварювання порівняно з існуючими технологіями та здійснити заміщення зубів розпушувача барового ланцюга імпортного виробництва на власні розробки.

Ключові слова: контактне зварювання опором, проміжний композиційний прошарок, твердосплавні матеріали, комп’ютерна система управління.

\author{
С.И. Кучук-Яченко, В.С. Гавриш, П.М. Руденко, \\ А.О. Наконечный, С.А. Шевчук, М.С. Завертанньй \\ Институт электросварки им. Е.О. Патона НАН Украины, \\ ул. Казимира Малевича, 11, Киев, 03150, Украина, \\ +380 44205 2370; +38044568 0486, office@paton.kiev.ua

\section{РАЗРАБОТКА ТЕХНОЛОГИИ И СОЗДАНИЕ ОПЫТНОГО ОБОРУДОВАНИЯ ДЛЯ КОНТАКТНОЙ СТЫКОВОЙ СВАРКИ СОПРОТИВЛЕНИЕМ ТВЕРДОСПЛАВНЫХ ЗУБЬЕВ РЫХЛИТЕЛЯ БАРОВОЙ ЦЕПИ ИЗ МАТЕРИАЛА ВК-8}

Введение. Необходимость сварки твердых сплавов со сталью возникает в инструментальной промышленности и в ряде процессов в машиностроительных отраслях при изготовлении твердосплавных заготовок, которые по своим габаритам или конфигурации не могут быть получены обычными методами порошковой металлургии.

Проблематика. Изготовление зубьев рыхлителя из твердых сплавов вольфрамокобальтовой группы ВК8 и стали 40Х является важной и актуальной задачей для повышения эксплуатационной надежности баровой цепи. В мировой практике при изготовлении ее зубьев используют технологию пайки в индукторе или газовым пламенем с припоями на основе серебра. Однако такой процесс отличается низкой производительностью и высокой себестоимостью.

Цель. Разработка высокоэффективной и относительно дешевой технологии изготовления зубьев рыхлителя баровой цепи и экспериментального оборудования для её реализации.

Материалы и методы. Исследования проводили на промышленных образцах из твердого сплава ВК-8 и стали 40Х. Микроструктуру сварных соединений исследовали методами оптической и электронной микроскопии.

Результаты. Разработано технологию контактной сварки сопротивлением твердосплавных зубьев рыхлителя баровой цепи из материала ВК-8 со сталью $40 \mathrm{X}$ с использованием промежуточного композиционного слоя. Создано опытное оборудование на основе машины для контактной сварки и компьютерной системы управления. Металлографические исследования сварных соединений показали отсутствие у них дефектов. Проведенные испытания сварных зубьев рыхлителя баровой цепи доказали, что они обеспечивают требуемый ресурс эксплуатации.

Выводы. Разработанная технология и оборудование позволяют значительно снизить себестоимость и повысить производительность процесса сварки по сравнению с существующими технологиями и провести замещение зубьев рыхлителя баровой цепи импортного производства на отечественные разработки.

Ключевые слова: контактная сварка сопротивлением, промежуточный композиционный слой, твердосплавные материалы, компьютерная система управления. 